\title{
Improving the Performance of SBR WWTP under the Effect of Organic Shock Load using Stoat Software
}

\author{
Hagar H Hassan ${ }^{1 *}$ and Medhat E Mostafa $^{2}$ \\ ${ }^{1}$ Department of Engineering Arab Academy of Science, Technology \& Maritime transport, Egypt \\ ${ }^{2}$ Department of Sanitary Engineering, Alexandria University, Egypt
}

Submission: June 12, 2019; Published: July 03, 2019

*Corresponding author: Hagar H Hassan, Arab Academy of science, technology \& Maritime transport, Alexandria, Egypt

\begin{abstract}
STOAT is a computer modelling tool designed to dynamically simulate the performance of WWTP. Modelling of integrated wastewater treatment plants (WWTP) using STOAT software proved to be extremely essential because it is time- and cost-effective. Furthermore, getting the overall picture for an entire system with relatively precise results, were quick responses for various scenarios are achieved. STOAT is used without any back-breaking tasks in contrast to laboratory experiments for predicting the effect of organic shock load. In this study, a model was built for a WWTP to predict organic sock load when doubled and how it would affect the plant. The results were extremely high and not acceptable when compared to the Egyptian environmental requirements. Therefore, another model was built to predict the exact percent of organic shock load that the plant can tolerate. The resulting data from the software proved the reliability of STOAT for modelling WWTPs. Consequently, improved effluent quality, reducing cost and the risk of consent failures.
\end{abstract}

Keywords: STOAT; WWTP; Organic shock load; Modelling; Sequence batch reactor; Simulations

Abbreviations: SBR: Sequence Batch Reactor; WWTP: Wastewater Treatment Plants; BOD: Biological Oxygen Demand; COD: Chemical Oxygen Demand; TSS: Total Suspended Solids; pH: Potential Hydrogen

\section{Introduction}

There is a substantial interest for using process models in wastewater treatment plant design. The process models are used to verify that the designed process or the effluents would meet the standard guidelines. Wastewater treatment plant (WWTP) models are used for improving the treatment process to solve treatment malfunctioning for plant robust operations [1]. Sequence batch reactors (SBR) systems can eradicate growth of most of the filamentous microorganisms, by controlling the operation of SBR cycle to overcome the hydraulic and organic shock load problems [2].

Due to the advantages of computer modelling of wastewater quality systems, it became a common tool used for WWTPs in eastern and central Europe [3]. Because of the flexibility of the designs and process control that can be attained by the modern technology, SBR process uses was never limited to the sewage treatment field only. However, it has been widely used in the field of biological treatment for the industrial wastewater, were organic chemicals exist and are difficult to treat. SBR processes are broadly known to be effectively automated, moreover, SBRs is known to save more than $60 \%$ of the operating expenses needed for a conventional activated sludge process also can attain high effluent quality in a very short aeration time [4].
Recently, modelling of WWTPs became an effective tool that proved countless positive effects on the performance of WWTPs, were modelling offers noticeable advantages when analysing the performance of treatment plants together with optimization and better control of the entire plant [5].

The organic pollutants biotransformation is carried out in the aeration tanks by using the biosensors effect existing at the aeration tank and the presence of the essential amount of dissolved oxygen in the water, pollutants are converted into a safe environmentally substance [6]. Extended aeration processes of SBR are frequently more efficient when handling organic loading and flow fluctuations, since there is higher detention time for the nutrients that are digested by microbes [7]. In order to model WWTPs, many modelling software are used to enhance the plants performance such as Sewage treatment operational analysis over time (STOAT). STOAT is a computer-based program designed to simulate the performance of WWTP. The software proved to be a helpful tool when studying the performance of WWTPs [8]. In this study, we prove the substantial importance of modelling WWTPs and how it can predict and analyze the amount of sewage outflowing from the plant. This was done by testing increased amount of the organic shock load and comparing the data to the effluent data disposed at the facility 


\section{Materials and Methods}

In this paper Hannoville WWTP in Alexandria, Egypt is used as a case study. SBR is the treatment process used at the Hannoville WWTP. The plant consists of three main unites; each one is not like the other neither in volume nor in dimension.

In this study, exclusively five parameters were considered at each unite in the Hannoville WWTP. These five parameters are biological oxygen demand (BOD), chemical oxygen demand (COD), total suspended solids (TSS), oxygen demand (DO) and potential hydrogen $(\mathrm{pH})$. Each parameter has an enormous effect on improving the entire WWTP's performance. A model was built by STOAT software using activated sludge model 1 (ASM1) [9] were each unite was separately studied due to the construction variations.

Organic shock load was applied to the Hannoville WWTP predicting the acceptable shock load for the entire WWTP by doubling the influent organic load, data were compared to the$$
\text { Table criteria and specifications forcertain substances when discharged }
$$

Table 1: Criteria and specifications for certain substances when discharged into the marine environment according to the Egyptian environmental requirements [10].

\begin{tabular}{|c|c|}
\hline Item & Maximum Limits of Criteria and Specifications (mg/l -Unless Otherwise Indicated) \\
\hline Temperature & $10^{\circ}{ }^{\circ} \mathrm{C}$ > average Temperature of receiving body \\
\hline $\mathrm{pH}$ & $6-9$ \\
\hline COD (Chemical Oxygen Demand) & 100 \\
\hline BOD (Biological Oxygen Demand) & 60 \\
\hline TSS (Total Suspended Solids) & 60 \\
\hline
\end{tabular}

According to the Egyptian specifications of law No. 48 of 1982 regarding the protection of the Nile river and its administrative regulations, the substance discharged from the Hannoville WWTP shall never exceed the effluent level, indicated in Table

\section{STOAT software results for evaluating the performance of Hannoville WWTP under organic shock load}

Table 2: Design parameters of the biological treatment technology at the Hannoville wastewater treatment plant [11].

\begin{tabular}{|c|c|c|c|c|}
\hline & & ABJ Units & Biogest Units & Extension \\
\hline \multicolumn{2}{|c|}{ Average Influents Flow Rate ( $\mathrm{m}^{3} /$ day) } & 10,000 & 10,000 & 30,000 \\
\hline \multicolumn{2}{|l|}{ Number of SBR unites } & 2 & 5 & 4 \\
\hline \multirow{3}{*}{ Dimensions } & $\mathrm{V}\left(\mathrm{m}^{3}\right)$ & 4,167 & 2,420 & 8,333 \\
\hline & $\mathrm{A}\left(\mathrm{m}^{2}\right)$ & 970 & 484 & 1,852 \\
\hline & $\operatorname{Depth}(\mathrm{m})$ & 4.3 & 5 & 4.5 \\
\hline \multirow{6}{*}{ Cycle period(min) } & Total & 360 & 570 & 480 \\
\hline & Fill & 90 & 140 & 120 \\
\hline & Aeration & 135 & 220 & 180 \\
\hline & Settle & 60 & 90 & 90 \\
\hline & Decant & 60 & 90 & 60 \\
\hline & Wastage & 15 & 30 & 30 \\
\hline Decant flow rate $\left(\mathrm{m}^{3} /\right.$ cycle $)$ & & 1,200 & 750 & \\
\hline Wastage sludge flow rate $\left(\mathrm{m}^{3} /\right.$ cycle $)$ & & 50 & 25 & 100 \\
\hline
\end{tabular}

Wastewater treatment values was taken by STOAT software to observe the performance of the entire plant under organic shock load which is classified into 3 main unites: First unite

$(A B J)$, second unite (Biogest) and third unite (ABJ-extension), also, studying the Parameters used for the performance evaluation which was TSS, BOD, COD, DO and pH for each unite. 
A model was built for the entire WWTP were each unite was applied with double the organic shock load that it usually accepts, the results exceeded the Egyptian environmental requirements. Consequently, more simulations were made till each unite reached the acceptable organic shock load. All data were compared when applying shock load and before applying any shock load to the plant. Design parameters, used as an input for STOAT software, of the Hannoville WWTP are shown in Table 2.
Since the results when doubling the organic shock load were too high when compared to the Egyptian environmental requirements, then another model was built showing the effluent data obtained when acceptable organic shock load was reached were it was $30 \%$ higher than before applying the organic load.

All effluent data for ABJ unite before applying organic shock load, after applying $2 \mathrm{x}$ and $1.3 \mathrm{x}$ organic shock load using STOAT software (as shown in Figure 1).

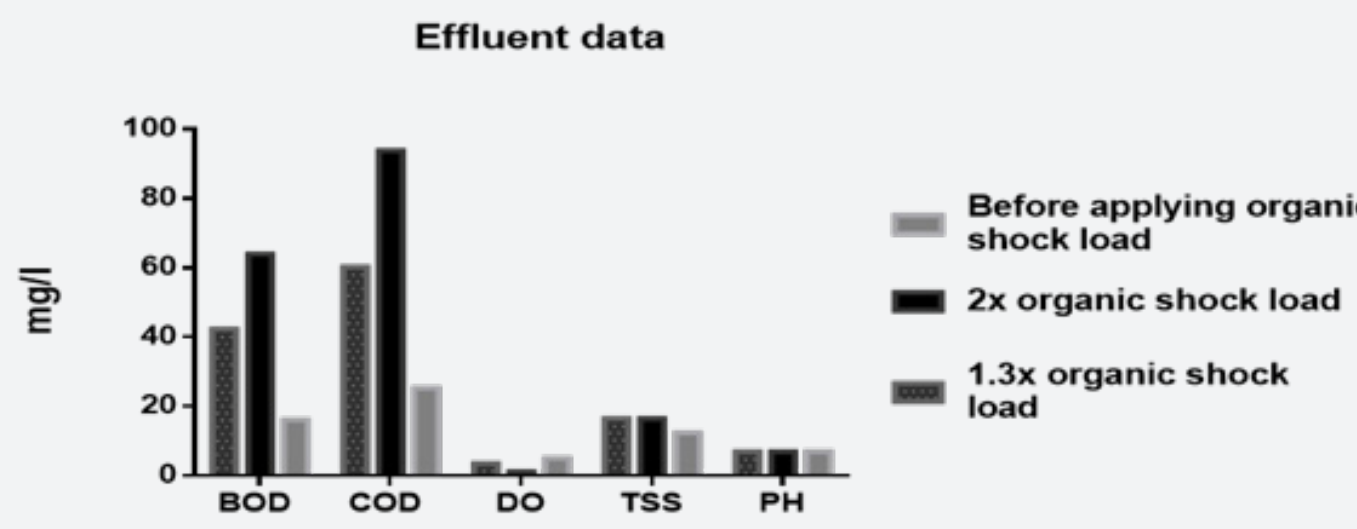

Figure 1: shows effluent data for ABJ unite before applying organic shock load, after applying $2 x$ and 1.3x organic shock load using STOAT software.

BOD effluent values before any organic shock load was applied ranged between $16.03 \mathrm{mg} / \mathrm{l} \& 16.05 \mathrm{mg} / \mathrm{l}$ were after doubling the load it ranged between $59.56 \mathrm{mg} / \mathrm{l} \& 70.88 \mathrm{mg} / \mathrm{l}$, since the effluent data after $2 \mathrm{x}$ shock load was too high and not acceptable when compared to the Egyptian environmental requirements (as shown in Table 1). Thus, simulations were made for the unite till the acceptable effluent data was predicted with $1.3 x$ organic shock load. The effluent data ranged from $40.11 \mathrm{mg} / \mathrm{l}$ to $43.98 \mathrm{mg} / \mathrm{l}$ which is adequate to the Egyptian environmental requirements (as shown in Table 1). Mean values were $63.93 \mathrm{mg} / \mathrm{l}$ for $2 \mathrm{x}$ shock load while after decreasing the load to $1.3 \mathrm{x}$ it became $42.33 \mathrm{mg} / \mathrm{l}$. Additionally, total mass was $1345.137 \mathrm{~kg}$ for $2 \mathrm{x}$ shock load while it decreased to $1004.904 \mathrm{~kg}$ in case of $1.3 \mathrm{x}$ shock load. The peak load was $1.88 \mathrm{~g} / \mathrm{s}$ and for $1.3 x$ load it became $1.02 \mathrm{~g} / \mathrm{s}$. The percentages of removal for BOD proved higher efficiency when organic shock load was applied with 1.3x (shown in Figure 2).
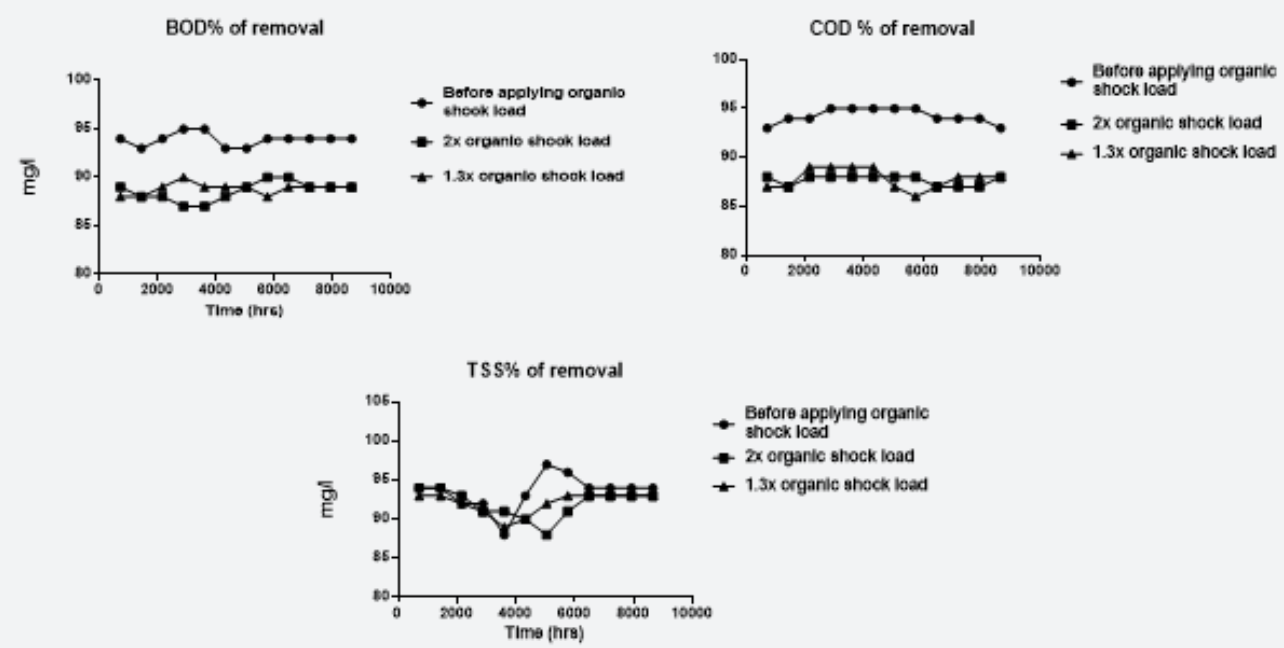

Figure 2: Shows $B O D, C O D$ and TSS removal percentages for first unite (ABJ) before applying organic shock load, after applying $2 x$ and $1.3 x$ organic shock load using STOAT software. 
COD effluent values before any shock load was applied in a range between $23.09 \mathrm{mg} / \mathrm{l}$ to $26.68 \mathrm{mg} / \mathrm{l}$ were after the shock load was doubled, it ranged from $92.01 \mathrm{mg} / \mathrm{l}$ to $97.35 \mathrm{mg} / \mathrm{l}$, and after applying $1.3 \mathrm{x}$ shock load it became $58.45 \mathrm{mg} / \mathrm{l}$ to $61.78 \mathrm{mg} / \mathrm{l}$. Mean values for COD in case of $2 \mathrm{x}$ load was $93.86 \mathrm{mg} / \mathrm{l}$ and turned out to be $60.17 \mathrm{mg} / \mathrm{l}$ under $1.3 \mathrm{x}$ organic load. Compared to the Egyptian environmental requirements (shown in Table 1) it was convenient. Meanwhile, total mass was $2154.48 \mathrm{~kg}$ for $2 \mathrm{x}$ shock load and after decreasing the load to $1.3 \mathrm{x}$ it became $2053.551 \mathrm{~kg}$. peak load was $2.01 \mathrm{~g} / \mathrm{s}$ and after $1.3 \mathrm{x}$ shock load was $1.57 \mathrm{~g} / \mathrm{s}$. also COD removal percentages were acceptable when compared to the Egyptian environmental requirements in case of applying 1.3 organic shock load to the ABJ unite shown in Figure 2.

Do effluent data ranged from $3.26 \mathrm{mg} / \mathrm{l}$ to $6.42 \mathrm{mg} / \mathrm{l}$ before any shock load was applied and after applying $2 \mathrm{x}$ shock load it ranged from $0.97 \mathrm{mg} / \mathrm{l}$ to $1.22 \mathrm{mg} / \mathrm{l}$, which was higher. After decreasing the load to $1.3 \mathrm{x}$ it ranged from $2.16 \mathrm{mg} / \mathrm{l}$ to $4.98 \mathrm{mg} / \mathrm{l}$. The increase in oxygen demand is very beneficial.

TSS effluent data before applying any shock load was from 9.48 to $19.08 \mathrm{mg} / \mathrm{l}$ and after applying $2 \mathrm{x}$ shock load ranged from 15.11 to $18.32 \mathrm{mg} / \mathrm{l}$, the change is insignificant, however, convenient. After applying $1.3 \mathrm{x}$ shock load data ranged from 15.03 to $17.87 \mathrm{mg} / \mathrm{l}$. The effluent TSS values was slightly changed and acceptable in all cases when compared to Egyptian environmental requirements (as shown in Table 1). TSS removal percentages were almost the same in all the previous discussed cases applied to the ABJ plant and all were acceptable (as shown in Figure 1).

$\mathrm{pH}$ values were almost identical in all cases and acceptable when compared to Egyptian environmental requirements Table 1.

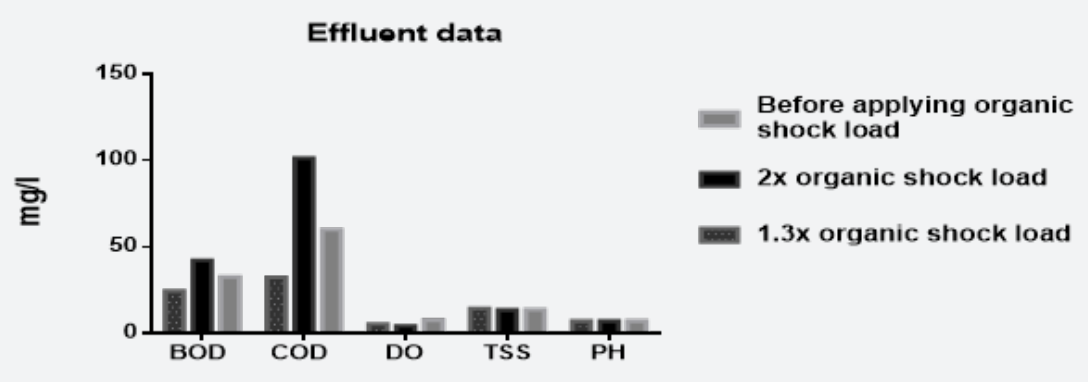

Figure 3: shows effluent data for Biogest unite before applying organic shock load, after applying $2 x$ and $1.3 x$ organic shock load using STOAT software.

The effluent data resulting from the BIOGEST unite before applying organic shock load, after applying 2x and 1.3x organic shock load using STOAT software (As shown in Figure 3).

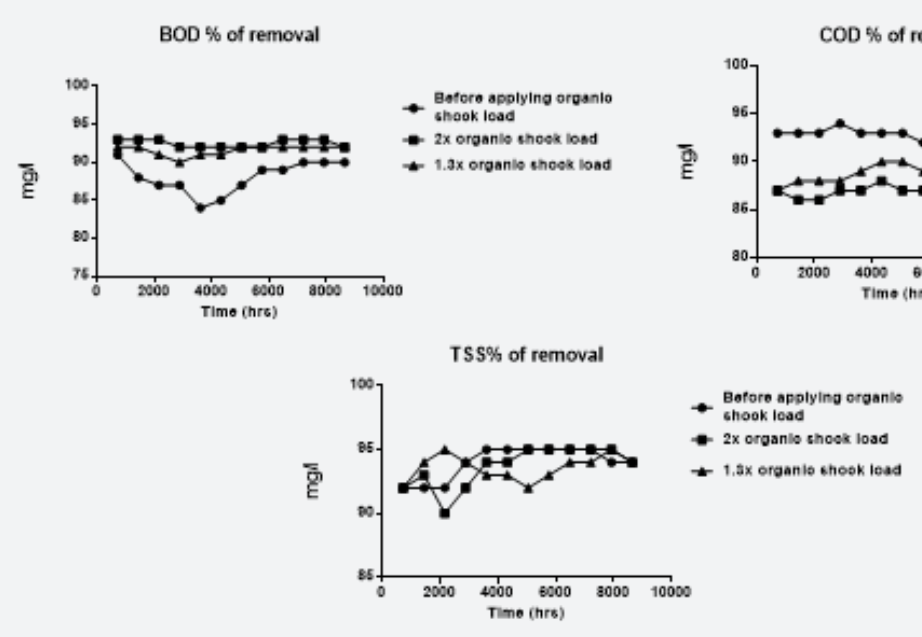

Figure 4: Shows BOD, COD and TSS removal percentages for first unite (Biogest unite) before applying organic shock load and after applying $2 x$ and $1.3 x$ organic shock load using STOAT software.

BOD effluent values before any organic shock load was applied it ranged between $23.08 \mathrm{mg} / \mathrm{l} \& 25.71 \mathrm{mg} / \mathrm{l}$ were after doubling the load it ranged between $40.08 \mathrm{mg} / \mathrm{l} \& 44.85 \mathrm{mg} / \mathrm{l}$.
Those effluent results were high as in the ABJ unite. After $1.3 \mathrm{x}$ shock load was applied, effluent values ranged from $31.78 \mathrm{mg} / \mathrm{l}$ to $33.56 \mathrm{mg} / \mathrm{l}$ which are acceptable when compared to the Egyptian 
environmental requirements (as shown in Table 1). Mean values were $42.21 \mathrm{mg} / \mathrm{l}$ for $2 \mathrm{x}$ shock load, while after decreasing the load to $1.3 \mathrm{x}$ it became $32.59 \mathrm{mg} / \mathrm{l}$. Additionally, total mass was $8060.29 \mathrm{~kg}$ for $2 \mathrm{x}$ shock load while it decreased to $1418.66 \mathrm{~kg}$ in case of $1.3 \mathrm{x}$ shock load, which is acceptable. Peak load was $10.261 \mathrm{~g} / \mathrm{s}$, nevertheless, for $1.3 \mathrm{x}$ load it became $2.98 \mathrm{~g} / \mathrm{s}$. Removal percentages (as shown in Figure 4) were acceptable in case of $1.3 x$ organic shock load.

COD effluent values before any shock load was within $30.17 \mathrm{mg} / \mathrm{l}$ to $33.82 \mathrm{mg} / \mathrm{l}$ were after the shock load was doubled it became from $100.37 \mathrm{mg} / \mathrm{l}$ to $102.76 \mathrm{mg} / \mathrm{l}$. As previously shown at the first unite, effluent values were not acceptable. After applying $1.3 \mathrm{x}$ shock load it became $58.34 \mathrm{mg} / \mathrm{l}$ to $60.78 \mathrm{mg} / \mathrm{l}$. Mean values for COD in case of $2 \mathrm{x}$ load was $101.35 \mathrm{mg} / \mathrm{l}$ and turned out to be $59.83 \mathrm{mg} / \mathrm{l}$ under $1.3 \mathrm{x}$ organic load which is within the acceptable limit. Total mass was $8060.29 \mathrm{~kg}$ for $2 \mathrm{x}$ shock load and after decreasing the load to $1.3 \mathrm{x}$ it became
$3808.62 \mathrm{~kg}$. Furthermore, peak load was $10.26 \mathrm{~g} / \mathrm{s}$ and after $1.3 \mathrm{x}$ shock load was $4.95 \mathrm{~g} / \mathrm{s}$. As shown in Figure 4, percentages of removal were acceptable when $1.3 \mathrm{x}$ organic shock load was applied.

DO effluent data ranged from $4.05 \mathrm{mg} / \mathrm{l}$ to $6.83 \mathrm{mg} / \mathrm{l}$ before any shock load was applied and after applying $2 \mathrm{x}$ shock load it was within the range $3.14 \mathrm{mg} / \mathrm{l}$ to $4.88 \mathrm{mg} / \mathrm{l}$, Meanwhile, when decreasing the load to $1.3 \mathrm{x}$ it ranged from $6.84 \mathrm{mg} / \mathrm{l}$ to $8.09 \mathrm{mg} / \mathrm{l}$. The results are convenient in case of $1.3 \mathrm{x}$ organic shock load.

TSS effluent data before applying any shock load was from 12.58 to $15.78 \mathrm{mg} / \mathrm{l}$ and after applying $2 \mathrm{x}$ shock load it ranged from 12.11 to $14.74 \mathrm{mg} / \mathrm{l}$. After applying $1.3 \mathrm{x}$ shock load data ranged from 12.34 to $14.34 \mathrm{mg} / \mathrm{l}$. the effluent. TSS values was slightly changed and acceptable in all cases when compared to Egyptian environmental requirements (as shown in Table 1). Removal percentage (shown in Figure 4) of TSS did not differ significantly in all cases.

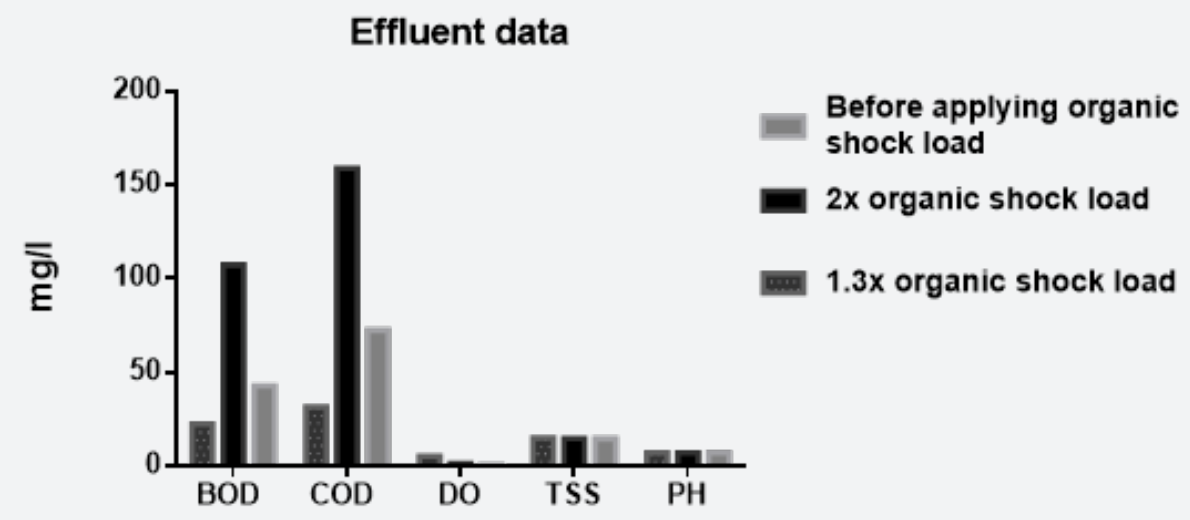

Figure 5: shows effluent data for ABJ extension unite before applying organic shock load, after applying $2 x$ and $1.3 x$ organic shock load using STOAT software.
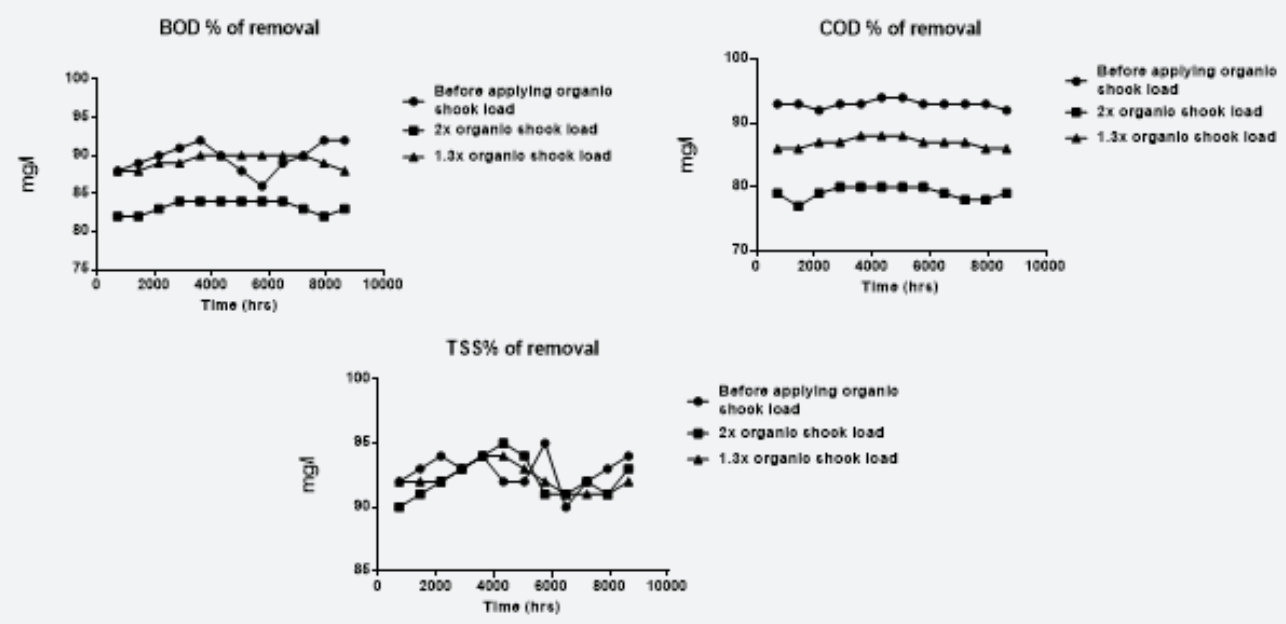

Figure 6: Shows BOD, COD and TSS removal percentages for first unite (ABJ extension unite) before applying organic shock load, after applying $2 x$ and $1.3 x$ organic shock load using STOAT software.

At the ABJ extension unite, all effluent data are shown (Figure 5) before applying organic shock load, after applying
$2 \mathrm{x}$ and $1.3 \mathrm{x}$ organic shock load using STOAT software. BOD effluent values before any organic shock load was applied 
ranging between $20.69 \mathrm{mg} / \mathrm{l} \& 24.2 \mathrm{mg} / \mathrm{l}$. On the other hand, after doubling the load, the effluent ranged between $103.49 \mathrm{mg} / \mathrm{l}$ $\& 110.79 \mathrm{mg} / \mathrm{l}$. Further simulations were done till the acceptable range was reached. After $1.3 x$ shock load was applied, effluent values ranged from $41.29 \mathrm{mg} / \mathrm{l}$ to $43.9 \mathrm{mg} / \mathrm{l}$ which are acceptable to the Egyptian environmental requirements (as shown in Table 1). Mean values were $107.28 \mathrm{mg} / \mathrm{l}$ for $2 \mathrm{x}$ shock load while after decreasing the load to $1.3 \mathrm{x}$ it became $42.73 \mathrm{mg} / \mathrm{l}$, additionally, total mass was $21991.6 \mathrm{~kg}$ for $2 \mathrm{x}$ shock load while it decreased to $12310.7 \mathrm{~kg}$ in case of $1.3 \mathrm{x}$ shock load. Peak load was $28.64 \mathrm{~g} / \mathrm{s}$ and for $1.3 \mathrm{x}$ load it became $20.41 \mathrm{~g} / \mathrm{s}$. BOD removal percentages were acceptable in case of $1.3 \mathrm{x}$ organic shock load (shown in Figure 6).

COD effluent values were between $30.04 \mathrm{mg} / \mathrm{l}$ to $32.76 \mathrm{mg} / \mathrm{l}$ before any shock load was applied. In addition, when the shock load was doubled, it ranged from $154.28 \mathrm{mg} / \mathrm{l}$ to $162.31 \mathrm{mg} / \mathrm{l}$, while, after applying $1.3 \mathrm{x}$ shock load it became $71.43 \mathrm{mg} / \mathrm{l}$ to $73.81 \mathrm{mg} / \mathrm{l}$. These results were found to be in the acceptable range when compared to the Egyptian environmental requirements (shown in Table 1). Mean values for COD in case of $2 \mathrm{x}$ load was $158.72 \mathrm{mg} / \mathrm{l}$ and turned out to be $72.44 \mathrm{mg} / \mathrm{l}$ under $1.3 \mathrm{x}$ organic load. Total mass was $35179.2 \mathrm{~kg}$ for $2 \mathrm{x}$ shock load and after decreasing the load to $1.3 \mathrm{x}$ it became $2324.5 \mathrm{~kg}$. Peak load was $31.97 \mathrm{~g} / \mathrm{s}$ and after $1.3 \mathrm{x}$ shock load it became $23.97 \mathrm{~g} / \mathrm{s}$. Removal percentages for COD (shown in Figure 6) was acceptable in case of applying $1.3 x$ organic shock load.

DO effluent data ranged from $4.19 \mathrm{mg} / \mathrm{l}$ to $6.73 \mathrm{mg} / \mathrm{l}$ before any shock load was applied and after applying $2 \mathrm{x}$ shock load it ranged from $1.12 \mathrm{mg} / \mathrm{l}$ to $1.9 \mathrm{mg} / \mathrm{l}$. However, when decreasing the load to $1.3 \mathrm{x}$ it ranged from $0.02 \mathrm{mg} / \mathrm{l}$ to $1.11 \mathrm{mg} / \mathrm{l}$. As a result, the increase in oxygen demand is not significant, but acceptable, due to the good extended aeration system.

TSS effluent data before applying any shock load was from 13.12 to $16.65 \mathrm{mg} / \mathrm{l}$ and after applying $2 \mathrm{x}$ shock load it was from 13.15 to $15.91 \mathrm{mg} / \mathrm{l}$. Subsequently, applying $1.3 \mathrm{x}$ shock load data ranged from 13.61 to $15.91 \mathrm{mg} / \mathrm{l}$, which is insignificant. Percentages of TSS removal were almost the same in all three cases (shown in Figure 6) and the results were all satisfactory according to the Egyptian environmental requirements.

\section{Conclusion}

STOAT software proved to be an advantageous tool when studying the performance of wastewater treatment plants. The significant impact shown by STOAT software in the field of wastewater treatment, facilitated the evaluation of Hannoville WWTPs and improving its performance.

In the presented study, WWTP was tested if it was adequate to receive $200 \%$ of the organic shock load that it typically receives. The effluent results exceeded the normal loading ranges when compared to the Egyptian environmental requirements. Consequently, further simulations were done till the acceptable organic load which was $130 \%$ of the typical organic loading. This case study shows the efficiency of modelling programs in the field of WWTP and how much it can solve problems that may occur in the long-term future for the entire SBR plant. The modelling will improve effluent quality, reduce cost and the risk of consent failures. This study elucidated the significant effect of modelling on the wastewater treatment environment and how it can predict such vital outcome in the long-term future with the least efforts and almost no cost.

\section{References}

1. Nagy-Kiss AM, Schutz G (2013) Estimation and Diagnosis Using Multi-Models with Application to A Wastewater Treatment Plant. Journal of Process Control 23(10): 1528-1544.

2. Sirianuntapiboon $\mathrm{S}$, Ungkaprasatcha 0 (2007) Removal of $\mathrm{Pb}^{2+}$ and $\mathrm{Ni}^{2+}$ By Bio-Sludge in Sequencing Batch Reactor (SBR) and Granular Activated Carbon-SBR (GAC-SBR) Systems. Bioresource Technology 98(14): 2749-2757.

3. Makinia J (2010) Mathematical Modelling and Computer Simulation of Activated Sludge Systems. Water Intelligence Online p. 408.

4. Qingyu W, Lin K (2017) Effect of Aeration Time on Preserved Wastewater Treatment of Ac-tivated Sludge Process. Asia-Pacific Engineering and Technology Conference (APETC 2017), pp. 1-6.

5. Nadja H, Vrečko D, Bordon C (2018) Plant-Wide Modelling for Assessment and Optimization of Upgraded Full-Scale Wastewater Treatment Plant Performance. Water Practice and Technology 13(3): 566-582.

6. Tao HJ, Xu H (2016) Dynamical Modeling and Intelligent Control of Aeration Process for Pollutants Degradation In Technics Of SBR. Materials Science Forum 859: 127-133.

7. Hasselkus W (2000) EPA wastewater technology fact sheets: We're looking for a few good technologies. Proceedings of the Water Environment Federation (10): 802-822.

8. Freni G, Maglionico M, Mannina G, Viviani G (2008) Comparison between a detailed and a simplified integrated model for the assessment of urban drainage environmental impact on an ephemeral river. Urban Water Journal 5(2): 87-96.

9. Coen F, Petersen B, Vanrolleghem PA, Vanderhaegen B, Henze M (1998) Model-Based Characterization of Hydraulic, Kinetic and Influent Properties of An Industrial WWTP. Water Science and Technology 37(12): 317-326.

10. Law number 4 of 1994 promulgating the environment law and its executive regulations, Ministry of environmental, Egypt.

11. Ahmed M Abou el yazid (2010) Evaluation of bio-logical wastewater treatment in hanovel plant. Master of engineering, faculty of engineering, Alexandria university, Egypt.

12. Nega R (2018) Microbial Environmental Risks Associated Sewage Sludge Disposal. Open Access Journal of Microbiology \& Biotechnology $3(2): 1-5$. 
Your next submission with Juniper Publishers will reach you the below assets

- Quality Editorial service

- Swift Peer Review

- Reprints availability

- E-prints Service

- Manuscript Podcast for convenient understanding

- Global attainment for your research

- Manuscript accessibility in different formats ( Pdf, E-pub, Full Text, Audio)

- Unceasing customer service

Track the below URL for one-step submission https://juniperpublishers.com/online-submission.php 